BISONIANA, LXX

\title{
Progress in Breeding European Bison and Domestic Cattle Hybrids and Casuistics in Cases of Immobilization and Pasteurelosis in Hybrids
}

\author{
Małgorzata KRASIŃSKA
}

\begin{abstract}
Krasińska M., 1979: Progress in breeding European bison and domestic cattle hybrids and casuistics in cases of immobilization and pasteurelosis in hybrids. Acta theriol., 24, 15: 201-210 [With 3 Tables].

The results of breeding studies obtained during the experiment on crossbreeding European bison with domestic cattle during the period from 1971-1976 are presented in this paper. A total of $15 \mathrm{~B}_{2}$ hybrids and $7 \mathrm{~B}_{3}$ hybrids were obtained during this period. In all, as from the start of our experiments, a total of 71 hybrids were obtained at Białowieża, as compared with a world total of 244 European bison hybrids over a period of 130 years. All $B_{1}$ cows were fertile, gestation lasting on an average 278.7 days, but of the 9 sexually mature $B_{2}$ cows only 5 produced young. Duration of gestation was on an average 275.3 days. $B_{3}$ generation heifers were sexually mature at the age of 11 months, that is, the earliest in comparison with cows of the other generations. 26 hybrids of different generations were shot for the purpose of morphophysiological examination. A description is given of immobilization of a $F_{1}$ male hybrid with etorphine chloride (M99), and cases of a pasteurelosis enzooty in backcross hybrids.

[Mammals Res. Inst., Polish Acad. Sci., 17-230 Białowieża, Poland].
\end{abstract}

\section{INTRODUCTION}

In the final stage of studies on crossbreeding European bison and domestic cattle, breeding of backcross generation hybrids, mating $F_{1}$, $B_{1}$ and $B_{2}$ females with two bulls of the black and white lowland cattle was continued from 1971-1976. Breeding studies were carried in accordance with the same principles and under unchanged conditions from those in previous years ( $\mathrm{K} \mathrm{r}$ a s iń s k a, 1967, 1971a).

Studies were continued on development of hybrids, their inheritance of morpho-physiological characteristics and fertility, and evaluation of their economic value (Krasińska, 1971b, 1976; Krasińska \& Pilarski, 1977; Pytel et al., 1977). A series of experiments was also carried out on the suitability of the preparation Rompun for immobilization of hybrids and one trial immobilization made using etorphine chloride (M99), castrating the hybrid at the same time.

Several cases of pasteureolosis were observed in the experimental reserve during the study period. 
This report is the seventh ${ }^{1}$ in turn and presents progress made in breeding studies and the course of experiments from the beginning of 1971 to the end of the experiments during the first half of 1976 .

\section{2. $F_{1}$ HYBRIDS}

2.1. Breeding Results

Only three hybrids of the first generation (Figa, Filon, Facet) lived in the experimental reserve during the period from 1971-1976. The cow Figa, covered by a bull of the black and white lowland breed, produced $2 \mathrm{~B}_{1}$ calves, and aborted at the end of gestation in May 1971 (Table 1). This cow was shot on 24 May 1976 in order to carry out morpho-physiological analyses.

Table 1

List of European bison and domestic cattle hybrids from Białowieża.

(An earlier list is to be found in the paper by $\mathrm{Kr}$ a sińs $\mathrm{k}$ a, 1971 a).

\begin{tabular}{|c|c|c|c|c|c|c|}
\hline No & Name \& & $\operatorname{sex}$ & Fat1 & Mother & Born & Died * \\
\hline \multicolumn{7}{|c|}{ Generation $\mathrm{B}_{1}$} \\
\hline 26 & un & M & bw & Fanny & 24 VIII 1966 & stillborn \\
\hline 27 & un & F & bw & Figa & 17 V 1971 & stillborn \\
\hline 28 & Feeria & $\mathrm{F}$ & bw & Figa & 17 V 1972 & 20 XI $1972 *$ \\
\hline 29 & Ferina & F & bw & Figa & 21 IV 1975 & 2 XII 1975 \\
\hline \multicolumn{7}{|c|}{ Generation $\mathrm{B} 2$} \\
\hline 10 & un & F & bw & Fewa & 19 III 1971 & 24 III 1971 \\
\hline 11 & Fenol & M & bw & Feska & 29 VI 1971 & 25 XI $1975^{*}$ \\
\hline 12 & Fenomen & M & bw & Femina & 13 VII 1971 & $28 \times 1975^{*}$ \\
\hline 13 & Fen II & M & bw & Fera & 24 VII 1971 & 18 XI $1975 *$ \\
\hline 14 & Fela II & $\mathrm{F}$ & bw & Felpa & 29 VII 1971 & 11 XI $1975^{*}$ \\
\hline 15 & Felga & $F$ & bw & Fenny & 26 IX 1971 & 25 XI $1974 *$ \\
\hline 16 & un & M & bw & Fera & 23 VII 1972 & stillborn \\
\hline 17 & un & M & bw & Felpa & 29 VII 1972 & stillborn \\
\hline 18 & Fetwa & $\mathrm{F}$ & bw & Fewa & 16 IV 1972 & 13 I 1975 * \\
\hline 19 & Fedala & $\mathrm{F}$ & bw & Feska & 5 V 1972 & $8 \times 1975^{*}$ \\
\hline 20 & Fenyl & M & bw & Fenny & 13 IX 1972 & 4 XII 1974 * \\
\hline 21 & Fenek & M & bw & Fenny & 11 VII 1974 & 11 XI $1975^{*}$ \\
\hline 22 & un & F & bw & Festynka & 15 VIII 1974 & stillborn \\
\hline 23 & Fena & $\mathrm{F}$ & bw & Fenny & 6 V 1975 & 2 XII $1975 *$ \\
\hline 24 & Feston & M & bw & Festynka & 30 VI 1975 & $18 \times \mathrm{XI} 1975^{*}$ \\
\hline \multicolumn{7}{|c|}{ Generation $\mathrm{B}_{\mathbf{8}}$} \\
\hline 1 & un & $\mathrm{F}$ & bw & Fega & 16 VII 1971 & 2 VIII 1971 \\
\hline 2 & Feda & $\mathrm{F}$ & bw & Fedala & 19 III 1974 & 11 V $1976^{*}$ \\
\hline 3 & Feliks & M & bw & Fela II & 3 V 1974 & $8 \operatorname{IV} 1976^{*}$ \\
\hline 4 & Ferta & F & bw & Festa & 14 VIII 1974 & 9 XII $1975^{*}$ \\
\hline 5 & un & F & bw & Fetwa & 6 XII 1974 & stillborn \\
\hline 6 & Fedra & $\mathrm{F}$ & bw & Fedala & 23 III 1975 & 30 III $1976^{*}$ \\
\hline 7 & Felba & F & bw & Fela II & 30 III 1975 & 30 III $1976^{*}$ \\
\hline
\end{tabular}

Abb.: bw - black and white lowland cattle; B1 - hybris $1 / 4$ European bison 3/4 cattle; $\mathrm{B}_{2}-$ hybrids $1 / 8$ European bison 7/8 cattle; $\mathrm{B}_{3}-1 / 16$ European bison $15 / 16$ cattle. * * Slaughtered, un - unnamed.

1 Earlier results of studies are contained in the following papers: Dehnel, 1960, 1961; Demiaszkiewicz, 1961; Krasińska, 1963, 1967, 1971a). 
The two $F_{1}$ bulls, Filon and Facet, were mated several times with both domestic black and white lowland cows and hybrid cows of different generations, but failed to sire progeny.

In the summer of 1972 the bull Filon escaped from the reserve through a broken fence into the area of the Primeval Forest, where it lived for 7 months. As it proved impossible to drive it into the reserve it was shot in February 1973 for slaughter analysis.

\subsection{Case of Immobilization of a $\mathbf{F}_{1}$ Hybrid}

The third hybrid of this generation, Facet, had caused considerable trouble within the breeding reserve for a long time. It was the most aggressive bull, particularly towards other males living in the reserve. Although it was infertile, it had an extremely strong sexual urge, and was particularly aggressive during the oestrus in cows. As its body weight $(1200 \mathrm{~kg}$ ) was very great during this period, this bull several times caused lasting injury in the cows it covered and in one case even injured the cow's spine. The bull also became dangerous to keepers. It was therefore decided to castrate the bull, immobilizing it with etorphine chloride (M 99), using a Paxarm gun. As the syringes projectil did not completely discharged their contents, the bull was only slightly stupefied and became even more excited. It was only $1^{1 / 2}$ hours later that we succeeded in shutting the bull up again and administering a full dose of $18 \mathrm{ml}$ of etorphine M 99, after which the bull finally subsided into a lying position 2 hours after the start of immobilization, but even so it was not rendered completely immobile, and was therefore given an additional intramuscular injection of $500 \mathrm{mg}$ of the preparation Rompun. After the bull became completely immobile, an epidural anaesthetic of $20 \mathrm{ml} 2 \%$ polocainum was given and castration carried out within 10 minutes. The bull remained in a state of deep narcosis after the operation, but began to wake after one hour, first of all lifting its head. After $1^{1 / 2}$ hours it began to raise the fore part of its body several times, got to its feet after three hours and went out into the enclosure. Within a few minutes the hybrids from the neighbouring enclosure broke down the fence and approached the bull as it sauntered about after coming to from the narcosis. One of the $B_{1}$ hybrids, Fell, ran up to Facet and fought with it for 15 minutes, when Facet fell down. Markedly accelerated respiration was observed in Facet, followed by its sudden death. Autopsy revealed hyperaemia pulmonum, oedema pulmonum, dilatatio cordis, myodegeneratio cordis, hydropericardium, degeneratio adiposa hepatis et infiltratio sanguineus multiplex subcutaneus. The results of the autopsy justify the conclusion that this bull must have suffered for 
some time from circulatory disturbance, leading to vasculostasis due to its considerable age (12.5 years) and its great body weight. The extraordinary effort due to excitement, and running over the 10 ha area of the enclosure for over $1^{1 / 2}$ hours in order to evade capture, exacerbated these disturbances and increased hyperaemia of the lungs. The lengthy narcosis and lying on one side for $3^{1 / 2}$ hours, followed by the fight, caused further deterioration in the animal's condition, leading to oedema pulmonum and death by suffocation.

The result of this immobilization leads to the following remarks and conclusions in relation to the use of the M 99 preparation for ungulates with very great body weight and of considerable age. It is essential to use a reliable gun loaded with syringes projectil of the greatest capacity. Every endeavour must be made not to over-excite the animal during capture operations. An antidote must be administered immediately the operation is completed, and if possible the animal should be isolated from other members of the group after immobilization. Aggressive behaviour towards immobilized animals has been observed in several cases in deer (S c a nlon et al., 1977), although it had never taken place in our reserve, in which hybrids and European bison had frequently been immobilized by means of the preparation Rompun, after which the animals failed to return to normal activity for some considerable time.

\section{BACKCROSS HYBRIDS}

\subsection{Breeding Results}

During the period under discussion there were $10(1,9) B_{1}$ hybrids $(1 / 4$ European bison, $3 / 4$ cattle) in the Białowieża reserve. Eight animals of this generation were shot for the purpose of morpho-physiological analysis (Table 2).

Table 2

Losses of European bison and domestic cattle hybrids in the experimental reserve from 1971 to 1976. Number of animals (males, females) is shown.

\begin{tabular}{cccc}
\hline Generation & Shot for analysis & Deaths or stillborn calves & Total \\
\hline $\mathrm{F}_{1}$ & $2(1,1)$ & $1(1,0)$ & $3(2,1)$ \\
$\mathrm{B}_{1}$ & $8(0,8)$ & $3(1,2)$ & $11(1,10)$ \\
$\mathrm{B}_{2}$ & $11(6,5)$ & $7(3,4)$ & $18(9,9)$ \\
$\mathrm{B}_{3}$ & $5(1,4)$ & $1(0,1)$ & $6(1,5)$ \\
Total & $26(8,18)$ & $12(5,7)$ & $38(13,25)$ \\
\hline
\end{tabular}

At the same time there were a further $17(7,10) \mathrm{B}_{2}$ hybrids $(1 / 8 \mathrm{Eu}-$ ropean bison, $7 / 8$ cattle) there - Table 1 . In October 1971 one of the cows of this generation, Fenicja, was killed by a falling tree. In July 
1973 it proved necessary to kill the bull Fenig, which had a permanently damaged leg owing to injuries sustained during a fight. Eleven $B_{2}$ hybrids were slaughtered (Table 2).

In 1972 there was a year's interval in reproduction of backcross generation hybrids, on account of the change of the domestic bull.

$B_{1}$ cows became sexually mature at the average age of 13.4 months, and oestrus was observed in them throughout the whole year. All sexually mature cows of this generation were fertile and produced 15 $(8,7) \mathrm{B}_{2}$ calves during this period, three of which were stillborn, and one died during the first week of life. The mortality index was therefore $27 \%$. Length of gestation in these cows was on an average 278.7 days (average deviation 2.7), that is, was slightly shorter than the average given for domestic cattle (A s d e 11, 1964).

$B_{2}$ cows became sexually mature later than $B_{1}$, that is, on an average at the age of 15.9 months, and oestrus occurred in them, similarly to $B_{1}$ cows, throughout the whole year. Of the 9 sexually mature cows of this generation four were infertile, and the remaining five produced 7 $\mathrm{B}_{3}$ calves during this time, one calf being stillborn and the heifer calf dying during the second week of life. Limitation of fertility in hybrid European bison and domestic cows in the identical generation also occurred at Askania Nova ( $\mathrm{Z} \mathrm{a} \mathrm{block} \mathrm{i} \mathrm{j,} \mathrm{1939).} \mathrm{Length} \mathrm{of} \mathrm{gestation} \mathrm{in}$ $\mathrm{B}_{2}$ cows was on an average 275.3 days (average deviation - 3.6) and therefore was shorter than the average data given for domestic cattle and $\mathrm{B}_{1}$.

Five animals $(1,4)$ of generation $B_{3}(1 / 16$ European bison and $15 / 16$ cattle) were included in the experiment (Table 1). Observations were made of the development of these animals, but the fertility of the heifers was not tested as the experiments came to an end. The heifers of this generation attained sexual maturity earlier, at the age of 11 months. A twoyear old bull of this generation, like all bulls of other backcross generations, was mated with hybrid cows, but calves were never obtained from such matings.

$\mathrm{B}_{3}$ hybrids were shot for the purpose of slaughter analysis in the final phase of the experiment.

\subsection{Pasteurelosis Enzooty in Backeross Generation Hybrids}

An outbreak of pasteurelosis was observed in the group of hybrids in 1975. During the heatwave in July 1975 the hybrid $B_{1}$ bull Fell was observed to have a swelling in the regio compedis, rapidly enlarging in the direction of the articulatio coxae, with simultaneous rise in temperature and accelerated respiration. The bull died in the evening of the 
same day, and the next case, the cow Fanny, became ill three days later. In this case the animal appeared morose, had a high temperature and swelling in the neck region. The cow died within 3 hours with symptoms of intensive dyspnoea. Swelling of the foreleg was next observed in another cow, Festa, and moroseness and symptoms of tympany in the four-month old heifer Fedra. Bacteriological examination made of the two dead animals confirmed the diagnosis of pasteurelosis. Two days after the outbreak of the enzooty all animals in the reserve were immunized against pasteurelosis with the serum Polisepsin. Immunization was repeated a week later, and all shelters for the animals and enclosures disinfected. After the treatment given the condition of the two ill animals improved and no new cases of illness were observed. This was the second infectious disease within the 17 year period of breeding hybrids, after the outbreak of rabies observed in $F_{1}$ generation animals in 1968 (K r a s ińs ka, 1971).

\section{DISCUSSION}

The experiments made at Białowieża from 1958-1976 provided material consisting of $71(31,40)$ hybrids with differing percentages of European bison and domestic cattle blood. This material formed $29 \%$ of the total number of hybrids obtained throughout the world from 1847-1977 (Table 3). As from the time the first hybrids were born in 1960 we carried out observations of the growth and development of hybrids of different generations ( $\mathrm{Kr}$ a s ińs ka, 1969, 1971b, 1978). A total of 51 hybrids were killed for dressing percentage usefulness ( $\mathrm{Sz}$ u lc et al., 1971; K r asińs ka, 1976). When making this analysis we also examined the morphology of the internal organs of hybrids, while the skeletons were prepared for further osteological examination. In addition histological examination was made of the reproductive system in $F_{1}$ and $B_{1}$ male hybrids ( $F$ ed y k \& $\mathrm{Kr}$ a siń $\mathrm{ska}, 1971$ ), and at the present time the material obtained from the remaining backcross males is being elaborated in order to discover the causes of the animals' infertility.

The material at our disposal enabled us to complete the zoological part of the Białowieża experiment by the middle of 1976. The results obtained provided confirmation for our opinion that it would be worthwhile continuing the experiments under breeding farm conditions. We considered that a realistic evaluation of the economic profitability of hybrid production could be made under such conditions and that supplementary experiments could be carried out on such questions as perfecting techniques for obtaining semen from European bison for artificial 


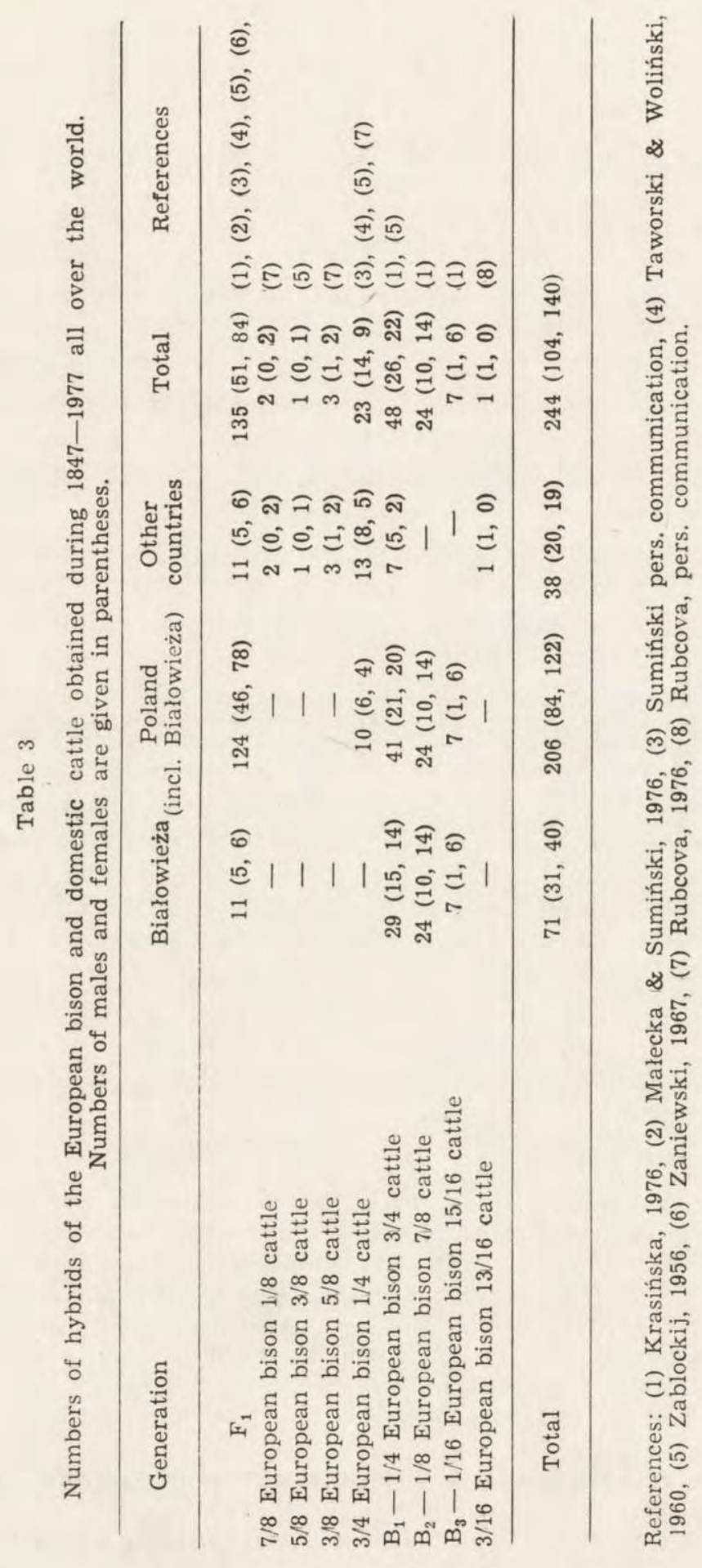


insemination, and also an evaluation of fodder consumption. Studies of this type could not be made in large forest enclosures. In April 1973 on the State Farm at Łękno (Poznań voivodship) work was begun on obtaining hybrids of European bison mated with cows of the black and white lowland and red Polish breeds, and hybrids of black and white lowland $X$ charolaise (M a łe cka \& S u miński, 1976). Up to April 1977 a total of $114(42,72)$ hybrids had been obtained there (S u m i ń$\mathrm{ski}$, pers. comm.) - Table 3 . The aim of this state farm was to produce young hybrids weighing from $350-500 \mathrm{~kg}$, pastured on farm wasteland. By 1976 year 147 cows had been inseminated with frozen European bison semen. Hybrid cows of the black and white lowland and charolaise breeds to have the highest fertility index with this type of insemination $(96 \%)$. It was found that only two out of the seven male European bison tested were capable of producing semen throughout the whole year and that such semen was suitable for freezing. This semen was obtained throughout the whole year by the appropriate means and by choice of fodder (M a le c k a et al., 1977).

The successful development of the experiment on European bison hybrids achieved at Łękno gives grounds for concluding that it will prove possible in the future to put the results of our studies into effect in practice. At the same time very successful results were obtained in the breeding of European bison, which makes it possible to ensure correct choice of breeding material essential to the production of hybrids.

\section{REFERENCES}

1. Asdell S. A., 1964: Patterns of mammalian reproduction. Comstoc Publ. 1-437. Ithaca, New York.

2. Dehnel A., 1960: Beobachtungen über Zusammenleben von Wisent und Hausrind. Acta theriol., 3, 14: $314-317$.

3. Dehnel A., 1961: Die ersten Hybriden zwischen Bos taurus dom. L. $\sigma^{*}$ und Bison bonasus (L.) ㅇ․ Acta theriol., 5, 3: 45-50.

4. Demiaszkiewicz W., 1961: Die Geburt eines Hybriden von Bison bonasus (L.) ơ und Bos taurus dom. L. ㅇ. Acta theriol., 5, 4: 51-56.

5. Fedyk S. \& Krasińska M., 1971: Studies on the spermatogenesis of domestic cattle and European bison hybrids. Acta theriol., 16, 29: 449-464.

6. Kra sińs k a M., 1963: Weitere Untersuchungen über Kreuzungen des Wisents, Bison bonasus (Linnaeus, 1758) mit dem Hausrind Bos taurus dom. Linnaeus, 1758. Acta theriol., 7, 14: $301-310$.

7. Krasińska M., 1967: Crosses of wisents and domestic cattle. V. Acta theriol., 12, 5: $67-80$.

8. Krasińska M., 1969: The postnatal development of $F_{1}$ hybrids of European bison and domestic cattle. Acta theriol., 14, 7: 69-117.

9. Krasińska M., 1971a: Hybridisation of European bison with domestic cattle. Part VI. Acta theriol., 16, 26: 413-422. 
10. Krasińska M., 1971b: Postnatal development of $B_{1}$ hybrids of European bison and domestic cattle. Acta theriol., 16, 27: 423-438.

11. Krasińska M., 1976: Hybridisation of the European bison and domestic cattle. Mimeographed: 1-22. Białowieża.

12. Krasińska M. \& Pilarski W., 1977: Biometric analysis of some internal organs of hybrids between the European bison and domestic cattle. Acta theriol., 22, 6: 121-139.

13. Ma lecka G. \& Sumiński E., 1976: Źubronie - nowy rodzaj mięsa. Przegląd hodowlany, 7: 12-13.

14. Małecka G., Lamperski B. \& Sumiński E., 1976: Podstawowe zagadnienia inseminacji krów nasieniem żubra. Przegląd hodowlany, 12: 15-19.

15. Pytel S., Krasińska M. \& Wegrzyn M., 1977: Morphology of the spleen in the European bison and its hybrids with domestic cattle. Acta theriol., 22, $7: 141-149$.

16. Rubcova R. A., 1976: Razvitje $3 / 8$ krovnych gibridov po zubru $v$ sravnenii s ich serstnikami černo-pestroj porody. Nauč. Tr Lenin. Sel-choz. Inst., 303: $106-110$.

17. Scanlor P. F., Mirarchi R. E., \& Wesson J. A., 1977: Aggresion toward immobilized white-tailed deer by other deer and elk. Wildl. Soc. Bull., 5, 4: 193-194.

18. Szulc M., Tropilo J. \& Krasińska M., 1971: Dressing percentage and domestic cattle hybrids. Acta theriol., 16, 32: 483-504.

19. Taworski T. \& Woliński Z., 1960: Krzyżówki międzygatunkowe zwieof the meat of European bison and domestic cattle hybrids. Acta theriol., 16, 32: $483-504$.

20. Z a blockij M. A., 1939: Tridcat' piat' let razvedenija zubrov i ich gibridov v Zooparke Askania Nova (1902-1937). [In: „Kavkazskij zubr«]. Glav. Upravl. po Zap. Zoopark. Zoosad.: 73-124. Moskva.

21. Z a blockij M. A. 1956: Gosudarstvennaja plemiennaja kniga zubrov i bizonov. Min. Sel. Choz. SSSR: 1-113. Moskva.

22. Zaniewski L., 1967: Observations on cross-breeding the European bison with domestic cattle of Polish Red breed. Acta theriol., 12, 33: 481-486.

Accepted, December 20, 1978.

Malgorzata KRASINSKA

\section{POSTĘP HODOWLI HYBRYDOW ŻUBRA Z BYDEEM DOMOWYM ORAZ KAZUISTYKA PRZYPADKOW IMMOBILIZACJI I PASTERELOZY U HYBRYDOW}

Streszczenie

W pracy przedstawiono wyniki hodowlane uzyskane $\mathrm{w}$ doświadczeniu nad krzyżowaniem żubrów $\mathrm{z}$ bydłem domowym w okresie 1971-76. W okresie tym uzyskano 15 mieszańców pokolenia $\mathrm{B}_{2}(7 / 8$ bydło, $1 / 8$ żubr $)$ oraz 7 sztuk pokolenia $\mathrm{B}_{3}$ $(15 / 16$ bydło, $1 / 16$ żubr) - Tabela 1 . Natomiast padło lub odstrzelono do analizy rzeźnej i morfo-fizjologicznej 38 hybrydów różnych pokoleń (Tabela 2). Łącznie 
uzyskano w Białowieży 71 hybrydów różnych pokoleń, przy 244 hybrydach żubra uzyskanych w okresie 130 lat na świecie (Tabela 3).

Wszystkie krowy pokolenia $\mathrm{B}_{1}$ były płodne, długość ciąży wynosiła u nich średnio 278,7 dni. Natomiast z 9 dojrzałych płciowo krów $B_{2}$ tylko 5 dało potomstwo. Długość ciąży wynosiła u nich średnio 275,3 dni, była więc krótsza od średnich danych dla krów $B_{1}$ i domowych. Jałówki $B_{3}$ dojrzały płciowo najwcześniej z krów pozostałych pokoleń, bo w wieku 11 miesięcy.

Opisano przypadek immobilizacji samca hybryda $F_{1}$ preparatem etorphine chloride oraz przebieg enzootii pasterelozy u hybrydów pokoleń wstecznych.

W dyskusji, w związku z zakończeniem białowieskiego eksperymentu, przedstawiono zakres dotychczas opracowanych zagadnień $w$ Białowieży oraz wyniki kontynuacji eksperymentu w warunkach fermy hodowlanej w Państwowym Gospodarstwie Rolnym Łękno województwo poznańskie. 